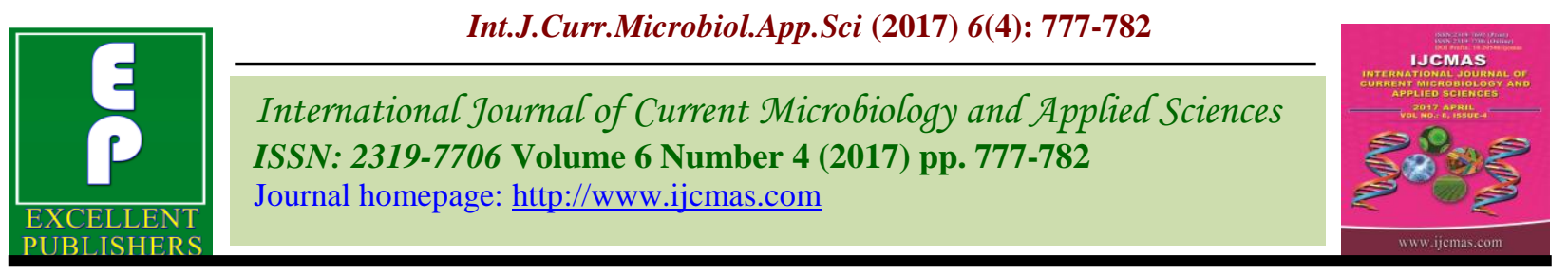

Original Research Article

https://doi.org/10.20546/ijcmas.2017.604.097

\title{
Effect of Sowing Time on Growth and Yield of Sweet Corn Cultivars
}

\author{
P. Keerthi*, G. Prabhakara Reddy and N. Sunitha \\ Department of Agronomy, S.V. Agricultural College, Tirupati-517 502, India \\ *Corresponding author
}

\begin{tabular}{|c|c|}
\hline & A B S T R A C T \\
\hline $\begin{array}{l}\text { K e y w o r d s } \\
\text { Growth, Green cob } \\
\text { yield, Green fodder } \\
\text { yield sweet corn } \\
\text { cultivars, Time of } \\
\text { sowing. }\end{array}$ & \multirow{3}{*}{$\begin{array}{l}\text { A field experiment was conducted at S.V. Agricultural College Wetland farm, } \\
\text { Tirupati to study the performance of sweet corn cultivars under varied times of } \\
\text { sowing in Southern Agro-Climatic Zone of Andhra Pradesh during rabi } 2011 \text {. } \\
\text { The treatments consisted of combination of two factors viz., three varieties } \\
\text { (Madhuri, Sugar } 75 \text {, Misthi) and four times of sowing (October first fortnight, } \\
\text { October second fort night, November first fortnight and November second } \\
\text { fortnight). Among the cultivars Misthi produced significant higher green cob } \\
\text { yield of } 17910 \mathrm{~kg} \text { ha- }^{1} \text { with maximum values of growth and yield attributes } \\
\text { over other cultivars. Sweet corn sown in first fortnight of October gives cob } \\
\text { yield of } 28291 \mathrm{~kg} \mathrm{ha}^{-1} \text { with maximum growth attributing characters than the } \\
\text { subsequent delayed sowing. }\end{array}$} \\
\hline Article Info & \\
\hline $\begin{array}{l}\text { Accepted: } \\
\text { 06 March } 2017 \\
\text { Available Online: } \\
10 \text { April } 2017\end{array}$ & \\
\hline
\end{tabular}

\section{Introduction}

Maize is the third most important cereal after rice and wheat in the world agriculture to provide food, feed and source for numerous industrial products. Maize is cultivated in tropical, sub-tropical and temperate countries of the world. India is the seventh largest producer of maize with 14.06 million tonnes of production from 7.18 million hectares, with a productivity of $1959 \mathrm{~kg} \mathrm{ha}^{-1}$ (Anonymous, 2011). In Andhra Pradesh, during the year 2011 , it is grown over an area of 7.44 lakh ha with a production of 39.53 lakh tonnes and productivity of $5317 \mathrm{~kg} \mathrm{ha}^{-1}$ (Annual Report 2011, ANGRAU, Hyderabad). Among the various specialty corns, sweet corn is a mutant type, with one or more recessive alleles in homozygous condition, which enables the endosperm to accumulate twice the sugar content as that of the seed corn (Creech, 1965). In order to best utilize the moisture, nutrients and solar radiation and for obtaining high seed yield of good quality, optimum time of sowing should be identified. Since the area under post-rainy season maize crop is increasing in recent years, it is essential to find out an optimum sowing with suitable cultivar for sweet corn crop during rabi season. Experimental evidence regarding the response of sweet corn cultivars to varied times of sowing on sandy loam soils in Southern Agro-climatic Zone of Andhra Pradesh is lacking. Keeping the facts in view, a field experiment entitled "Performance of sweet corn cultivars under varied times of sowing" was conducted during rabi, 2011-12. 


\section{Materials and Methods}

A field experiment was conducted during rabi, 2011-12 at S.V. Agricultural College wetland farm, Tirupati of Acharya N.G. Ranga Agricultural University, Andhra Pradesh to study the "Performance of sweet corn cultivars under varied times of sowing during rabi". The experiment was laid out in a randomized block design with factorial concept, replicated thrice. The treatments consisted of combination of two factors viz., three cultivars (Madhuri, Sugar 75 and Misthi) and four times of sowing (October first fortnight, October second fort night, November first fortnight and November second fortnight). The soil of the experimental field was sandy loam in texture with $\mathrm{pH} 6.5$ and 0.24 per cent organic carbon. The available nitrogen, phosphorus and potassium were $213 \mathrm{~kg} \mathrm{ha}^{-1}, 29.3 \mathrm{~kg} \mathrm{ha}^{-1}$ and $281 \mathrm{~kg} \mathrm{ha}^{-1}$ respectively.

All the management practices were adopted for sweet corn cultivation as per the recommendations of Acharya N.G. Ranga Agricultural University, A.P. The data recorded on various parameters of crop was subjected to statistical scrutiny by the method of analysis of variance as outlined by Panse and Sukhatme (1985).

\section{Results and Discussion}

\section{Effect on growth}

The growth of sweet corn cultivars was measured in terms of plant height, dry matter accumulation varied significantly under different times of sowing (Table 1). The sweet corn cultivars differed significantly with regard to growth parameters. At 30 and 60 DAS tallest plants were observed with Misthi cultivar which was significantly superior to Madhuri which in turn on par with
Sugar 75. However, at harvest the highest plant height was recorded with cultivar Misthi, which was comparable with Madhuri whereas, Madhuri was significantly superior over Sugar 75 during 2011-12. The plant height decreased with delay in sowing at all the growth stages significantly. However at 60 DAS and at harvest, October second fortnight was comparable to November first fortnight which in turn on par with November second fortnight during 2011-12, crop sown during first fortnight of October resulted in the tallest plants, which might be due to favourable climatic conditions that prevailed during the crop growth period, while second fortnight of November recorded lesser plant height. This might be due to crop experienced lesser than the optimum temperatures required by the crop during its growth period, which adversely affected the growth, decreasing the plant height. Similar findings were reported by Prodhan (2001); Chavan and Chavan (2010) and Marjan et al., (2010).

The data pertaining to dry matter accumulation are presented in table 1 . The dry matter accumulation increased with advancement in crop age during 2011-12. Among the cultivars, Misthi recorded highest dry matter accumulation which was significantly superior over Sugar 75 and Madhuri at all the growth stages. The dry matter accumulation decreased significantly with delay in sowing at all the growth stages i.e., 30, 60 DAS and at harvest (Table 1). However, at 30 DAS the highest dry matter production was recorded with October first fortnight which was comparable with October second fortnight and November first fortnight. However, November first fortnight was significantly superior to November II FN. Dry matter production in a crop community mostly depends on LAI, photosynthetic rate and leaf angle, but the dry matter production per unit area depends on number of plants per unit area and dry matter production per plant. 
Dry matter production was related to productivity constitutes an important factor in source-sink relationship The dry matter production was maximum with Misthi cultivar compared to rest of the cultivars might be due to more plant height, more number of leaves and more leaf area. Dry matter production was maximum with October first fortnight compared to rest of the times of sowing at all the stages of the crop growth. This might be due to better plant stature with higher plant height and leaf area (Nandal and Agarwal, 1991) and optimum weather conditions prevailing during the crop growth. The lowest dry matter produced during November second fortnight might be due to reduced plant height and lower LAI throughout the crop growth.

\section{Effect on yield and harvest index}

The results pertaining to green cob yield, green fodder yield and harvest index in relation to sweet corn cultivars and times of sowing are presented in table 2. Sweet corn cultivars differed significantly in green cob yield. The highest green cob yield $(17,910 \mathrm{~kg}$ $\mathrm{ha}^{-1}$ ) was recorded by the cultivar Misthi, which was significantly superior to all other cultivars.

Table.1 Plant height $(\mathrm{cm})$ and dry matter production $(\mathrm{kg} / \mathrm{ha})$ of sweet corn cultivars as influenced by different times of sowing

\begin{tabular}{|c|c|c|c|c|c|c|}
\hline \multirow[t]{2}{*}{ Treatments } & \multicolumn{3}{|c|}{ Plant height $(\mathbf{c m})$} & \multicolumn{3}{|c|}{ Dry matter production (kg/ha) } \\
\hline & 30 DAS & 60 DAS & $\begin{array}{c}\text { At } \\
\text { harvest }\end{array}$ & 30 DAS & 60 DAS & $\begin{array}{c}\text { At } \\
\text { harvest }\end{array}$ \\
\hline \multicolumn{7}{|l|}{ Cultivars } \\
\hline Madhuri & 61.3 & 131.4 & 155.7 & 561 & 5484 & 5850 \\
\hline Sugar 75 & 59.3 & 130.5 & 151.5 & 612 & 7060 & 7902 \\
\hline Misthi & 67.5 & 136.5 & 158.2 & 687 & 7772 & 8753 \\
\hline $\mathrm{CD}(\mathrm{P}=\mathbf{0 . 0 5})$ & 5.5 & 1.7 & 2.5 & 10 & 123 & 119 \\
\hline \multicolumn{7}{|l|}{ Times of Sowing } \\
\hline October I FN & 73.5 & 135.7 & 159.2 & 640 & 7130 & 8087 \\
\hline October II FN & 65.5 & 133.1 & 155.0 & 629 & 6854 & 7828 \\
\hline November I FN & 56.2 & 131.6 & 153.9 & 619 & 6710 & 7503 \\
\hline November II FN & 55.7 & 130.8 & 152.5 & 592 & 6395 & 6589 \\
\hline $\mathrm{CD}(\mathrm{P}=\mathbf{0 . 0 5})$ & 6.4 & 1.9 & 2.9 & 11 & 142 & 137 \\
\hline
\end{tabular}


Table.2 Green cob yield $\left(\mathrm{kg} \mathrm{ha}^{-1}\right)$ and Green fodder yield $\left(\mathrm{kg} \mathrm{ha}^{-1}\right)$ Biological yield $\left(\mathrm{kg} \mathrm{ha}^{-1}\right)$ and Harvest index of sweet corn cultivars as influenced by different times of sowing

\begin{tabular}{|l|c|c|c|c|}
\hline Treatments & $\begin{array}{c}\text { Green cob yield } \\
\left(\mathbf{k g ~ h a}^{-\mathbf{1}}\right)\end{array}$ & $\begin{array}{c}\text { Green fodder } \\
\text { yield }\left(\mathbf{k g ~ h a}^{-\mathbf{1}}\right)\end{array}$ & $\begin{array}{c}\text { Biological } \\
\text { yield }\left(\mathbf{k g ~ h a}^{-\mathbf{1}}\right)\end{array}$ & $\begin{array}{c}\text { Harvest Index } \\
(\%)\end{array}$ \\
\hline Cultivars & 12508 & 16476 & 28983 & 43.01 \\
\hline Madhuri & 16482 & 20045 & 36527 & 44.86 \\
\hline Sugar 75 & 17910 & 21924 & 39834 & 45.02 \\
\hline Misthi & $\mathbf{3 5 0}$ & $\mathbf{3 8 1}$ & $\mathbf{4 8 8}$ & $\mathbf{0 . 7 8}$ \\
\hline CD(P=0.05) & 18291 & 21641 & 39931.86 & 45.68 \\
\hline Time of Sowing & 16375 & 19763 & 36138.58 & 45.23 \\
\hline October I FN & 14784 & 18994 & 33778.65 & 43.71 \\
\hline October II FN & 13084 & 17527 & 30610.34 & 42.56 \\
\hline November I FN & $\mathbf{4 0 4}$ & $\mathbf{4 4 0}$ & $\mathbf{5 6 4}$ & $\mathbf{0 . 9}$ \\
\hline November II FN & & & & \\
\hline CD(P=0.05) & & & & \\
\hline
\end{tabular}

Fig.1 Regression line showing the relationship of biological yield ( $\mathrm{kg} / \mathrm{ha}$ ) with seed yield ( $\mathrm{kg} / \mathrm{ha})$

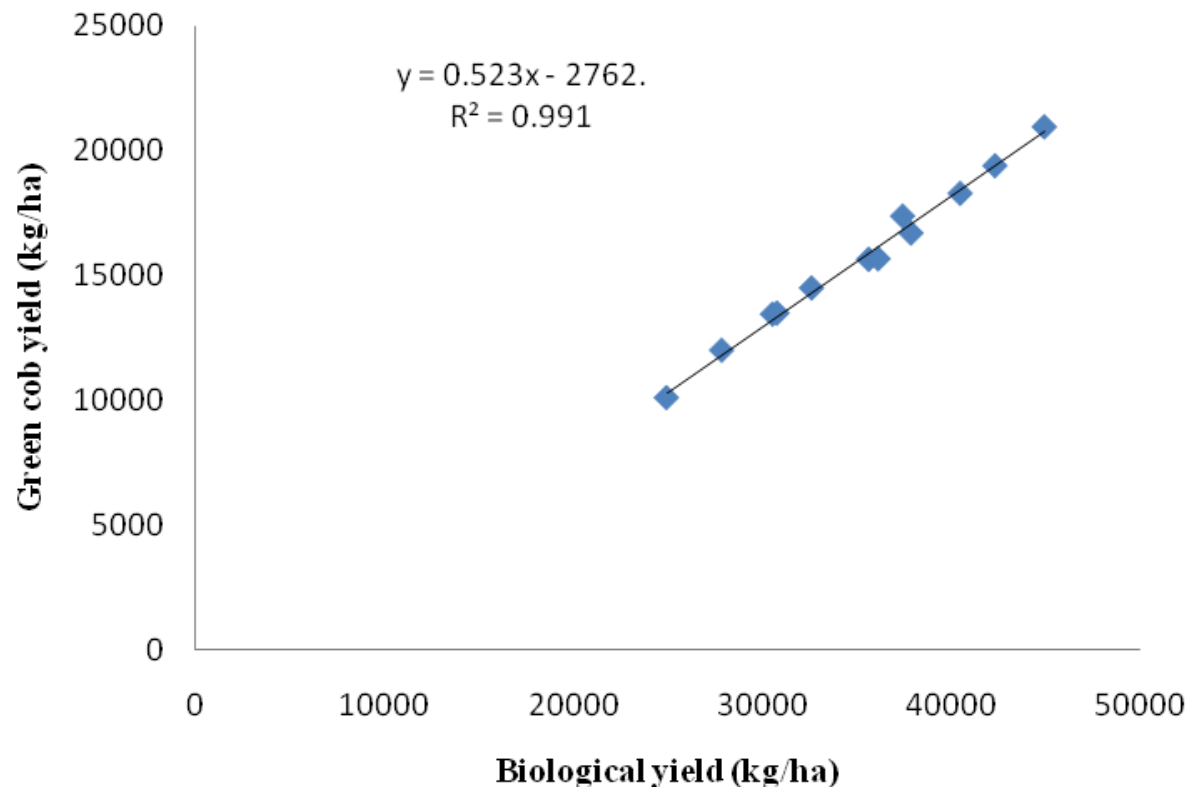


Fig.2 Regression line showing the relationship of Harvest index (\%) with green cob yield (kg/ha)

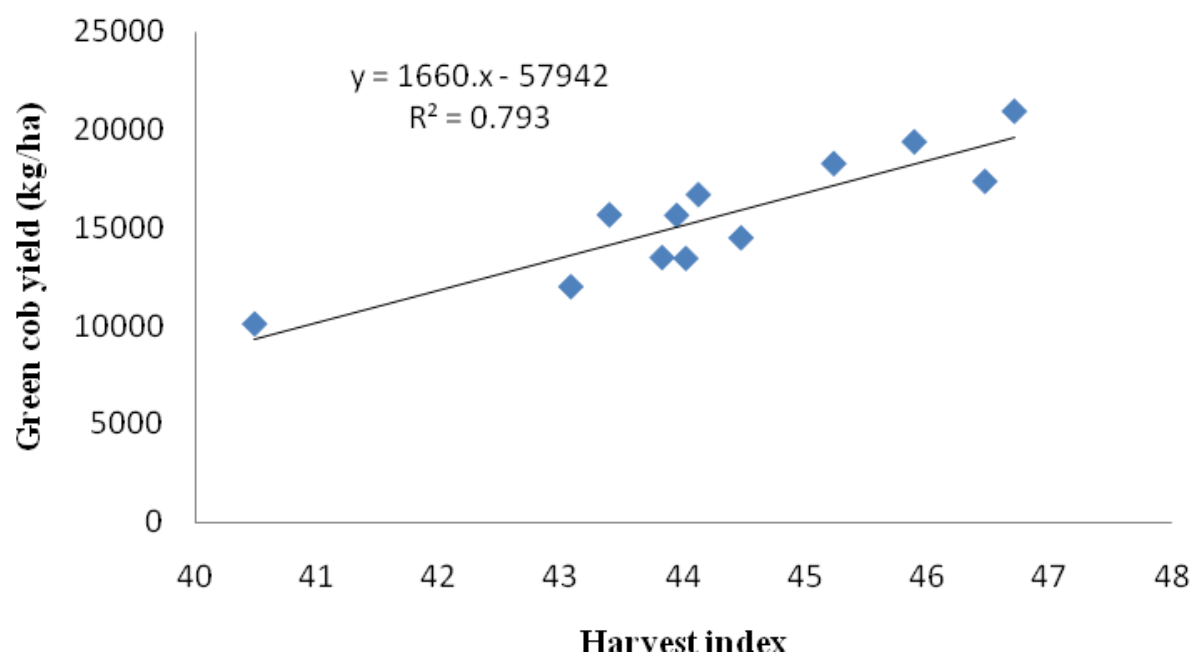

Green cob yield recorded with all the cultivars showed significant disparity with each other. The lowest green cob yield was recorded by the cultivar Madhuri $\left(12,508 \mathrm{~kg} \mathrm{ha}^{-1}\right)$. The difference in cob yield among the time of sowing was obtained to be significant. The highest green cob yield $\left(18,291 \mathrm{~kg} \mathrm{ha}^{-1}\right)$ was recorded during October first fortnight, which was significantly superior to all other times of sowing. Sowing during November second fortnight recorded the lowest green cob yield $\left(13,084 \mathrm{~kg} \mathrm{ha}^{-1}\right)$ during 2011-12. Early (October first fortnight) sown crop received the optimum environment conditions required for better crop growth in terms of plant height, and dry matter accumulation. The significantly positive association between biological yield with growth parameters namely plant height $(\mathrm{r}=0.36)$ and dry weight $(\mathrm{r}=0.78)$. Similar findings were reported by Cardoso and Soccol (2008); and Chavan and Chavan (2010).

Among the cultivars, the highest biological yield $\left(39,834 \mathrm{~kg} \mathrm{ha}^{-1}\right)$ was recorded by the cultivar Misthi, which was significantly superior to all other cultivars. Biological yield recorded with all the cultivars showed significant disparity with each other (Table 2).
The response of biological yield of sweet corn to different times of sowing was obtained to be significant. The maximum biomass production $\left(39,932 \mathrm{~kg} \mathrm{ha}^{-1}\right)$ was recorded with October first fortnight which was significantly higher when compared to crop sown on October second fortnight $\left(36,138 \mathrm{~kg} \mathrm{ha}^{-1}\right)$, November first fortnight $\left(33,779 \mathrm{~kg} \mathrm{ha}^{-1}\right)$ and November second fortnight $\left(30,610 \mathrm{~kg} \mathrm{ha}^{-1}\right)$ during 2011-12. The stronger source is required for the stronger sink. The higher biological yield was found significantly associated with higher green cob yield of sweet corn $(\mathrm{r}=0.99)$. This clearly shows the biological yield increased by any input or management practice will automatically increase the cob yield of sweet corn. The green cob yield of sweet corn can also be estimated through biological yield with the regression equation (Fig. 1; Cob yield = $2762+0.523$ biological yield, $r^{2}=0.99$ ). These results were in agreement with the findings of Prodhan (2001) and Chavan and Chavan (2010).

The data pertaining in table 2 indicates that harvest index (H.I) of sweet corn cultivars was influenced significantly by the different dates of sowing during 2011-12. The highest 
harvest index was recorded with Misthi cultivar (45.02) and minimum by Madhuri (43.01). The maximum harvest index was observed in October first fortnight (45.68), followed by October second fortnight sown crop (45.23), followed by crop sown at November first fortnight (43.71). The minimum harvest index was obtained (42.56) when crop sown on November second fortnight during 2011. Harvest index is the parameter which dependent on seed yield $(\mathrm{r}=$ $0.89)$ and biological yield $(r=0.84)$. This shows that harvest index was more associated with seed yield than biological yield. The harvest index can also be computed from the seed yield with regression equation $(\mathrm{SY}=$ $57942+1660 x H I, \quad r^{2}=0.79$ (Fig. 2). These results were in agreement with the findings of Prodhan (2001) and Chavan and Chavan (2010).

\section{References}

Annual report of Regional Agricultural Research Station. $47^{\text {th }}$ ed. 2011. Acharya N.G. Ranga Agricultural University, Hyderabad.

Anonymous. 2011. www.indiastat.com

Chavan, P.G., and Chavan, S.A. 2010. Effect of sowing dates and plant spacing on growth, yield and yield attributes of rabi sweet corn under lateritic soils of Konkan. J. Indian Society Coastal Agri. Res., 28(1): 55-57.

Cardoso, C.O. and Soccol, O.J. 2008. Corn performance with late sowing in planalto Catarinense, Brazil, simulated with CERES-Maize model. Brazilian Arch. Biol. Technol., 51(4): 655-664.

Creech, R.G. 1965. Genetic control of carbohydrates synthesis in maize endosperm. Genetics, 52: 11751186.

Marjan, P., Rahim, N. and Reza, Soleimani. 2010. Efficiency of some sweet corn hybrids at two sowing dates in central Iran. Middle-East J. Scientific Res., 6(1): 51-55.

Nandal, D.P.S. and Agarwal S.K. 1991. Response of winter maize to sowing dates, irrigation and nitrogen. Indian $J$. Agron., 36(2): 239-242.

Panse, V.G. and Sukhatme, P.V. 1985. Statistical Methods for Agricultural Workers. Indian Council of Agricultural Research, New Delhi, PP 100-174.

Prodhan, H.S. 2001. Influence of appropriate cultivar and sowing dates on rabi maize productivity. Indian J. Agri. Sci., 71(1): $55-56$.

\section{How to cite this article:}

Keerthi, P., G. Prabhakara Reddy and Sunitha, N. 2017. Effect of Sowing Time on Growth and Yield of Sweet Corn Cultivars. Int.J.Curr.Microbiol.App.Sci. 6(4): 777-782.

doi: https://doi.org/10.20546/ijcmas.2017.604.097 